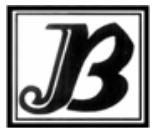

J. bio-sci. 20: 49-55, 2012

ISSN 1023-8654

http://www.banglajol.info/index.php/JBS/index

\title{
REPELLENT ACTIVITY OF ABROMA AUGUSTA EXTRACTS AGAINST TRIBOLIUM CASTANEUM (HERBST) ADULTS
}

\author{
Omar Ali Mondal ${ }^{1}$, Jahurul Haque ${ }^{1}$, Esarul Haque ${ }^{2}$,Ataur Rahman Khan ${ }^{* 1}$ \\ ${ }^{1}$ Department of Zoology, University of Rajshahi, Rajshahi-6205, Bangladesh, 2Department of Zoology, \\ Premtali Degree College, Godagari-Rajshahi,Bangladesh
}

\begin{abstract}
Context: Repellency test can play an important role in special environmental conditions.

Objectives: The main objective of this study was to make a standard protocol to control the pest by screening the test materials using adult beetles by repellency test to see whether or not the extracts contain any potential to repel the stored grain pest.

Materials and Methods: The experiment was conducted in choice chamber, which was divided by half filter paper discs (Whatman No. 40, diameter $9 \mathrm{~cm}$ ). One half of the filter paper was loaded with untreated (control) and the other half was loaded with the extract of $A$. augusta. All the $\mathrm{CHCl}_{3}$ extracts were separately applied onto each of the half-discs and allowed to dry out in the air for 10 mins. Each treated half-disc was then attached lengthwise, edge-to-edge, to a control half-disc with adhesive tape and placed in petri dishes. The orientation of the same was changed in the replicates to avoid the effects of any external directional stimulus affecting the distribution of the test insects Tribolium castaneum (Herbst). Ten adult insects were released in the middle of each of the filter-paper circles and each test was replicated five times.

Results: All the test extracts of seed, leaves, root wood, stem bark and stem wood of $A$. augusta collected in chloroform showed repellent activity against adult beetles of $T$. castaneum at dose levels of $314.540,157.270,78.635,39.318,19.659$ and, $9.831 \mu \mathrm{g} / \mathrm{cm}^{2}$ on filter paper. According to the intensity of repellency the results could be arranged in the order: stem bark >seed $>$ root wood $>$ leaf $>$ stem wood and in all the cases significant differences were obtained.

Conclusion: The present results revealed that $A$. augusta extracts can be used as a reduced risk repellent compound in the grain and cereal stores to manage the population of $T$. castaneum. The results also seen to be encouraging when there is a greater need for environment-friendly pesticides then ever before.
\end{abstract}

Key words: Abroma augusta, repellent activity, Tribolium castaneum.

\section{Introduction}

Natural products derived from plants, as an alternative to conventional insecticides for insect control, is nowa-days very popular among the pest control experts. Botanical pesticides are more readily biodegradable and therefore, are less likely to contaminate the environment. Moreover, the plant-derived compounds break down readily in soil and are not stored in plant or animal tissues. However, they might have a certain extent of toxicity to kill insects, thus affect the food chain or food web and create an imbalance in the ecosystem as an ultimate consequence. Repellents in that case could be a better solution for the management of the stored product pests, among others. Plant-derived pesticides are being subjected to produce insect repellents or insect antifeedants for safer protection of field crops and stored grains with eco-friendly means of sustainable development.

\footnotetext{
* Corresponding author
} 
Abroma augusta L., locally known as Ulatkombal, is a shrub and small tree, attaining a height of 3-5 meters with horizontal and velvety branches. The branches and branchlets are downy. The leaves are alternate. The dry roots have $0.5-1.0 \mathrm{~mm}$ thick, highly fibrous, brown barks; the thickness of the bark varies according to the age and girth of the root. When freshly cut the root produces a thick gummy substance. The outer surface of the bark is dull brown and longitudinally wrinkled with small warty markings; the outer surface is whitish yellow and finely longitudinally striate. The root bark is test less, slimy, odourless, and tough, but not brittle. When soaked in cold water for 3-4 days, the bark produces slimy mucilage which can be extracted (Anonymous 2006, Nandkarni 2002).

Being a medicinal plant, $A$. augusta contains antipathogenic properties. Almost all the parts of the plant are used in the treatment of diseases. The root wood and root bark are reputed remedies as an emmenagogue and uterine tonic, used in ammenorrhoea for congestive and nervous dysmenorrhoea and prescribed during irregular menses. The utility of $A$. augusta in uterine hemorrhage might be due to the presence of the magnesium salts (Nandkarni 2002). The leaves are reported to be useful in treating uterine disorders, diabetes, rheumatic pains of joints, and headache with sinusitis. The cold aqueous infusion of the fresh leaves and twigs have been reported to be demulcent and very efficacious in gonorrhea. The leaves are used as aphrodisiac as a sex stimulant. A. augusta is also used in stomachache, diabetes, dermatitis, and in whitish discharge in urine in men (Rahamtullah et al. 2010).

Powdered roots are used as abortifacient and anti-fertility agent. Leaves are useful in treating uterine disorders, diabetes, rheumatic pain of joints, and headache with sinusitis (Prajapati et al., 2003). Leaves and stem are demulcent and an infusion of fresh leaves and stem in cold water is very efficacious in gonorrhea(Nandkarni 2002). The root-bark is used as an emmenagogue and uterine tonic. The action of dried roots as well as the sap of the fresh root has been studied (Kirtikar and Basu 1999). The leaves and stems of A. augusta were used by the traditional healers of Bogra district, but the bark of roots were used by the traditional healers of Jessore district (Hanif et al. 2010). A combination of aqueous extract of dried powder of root and leaves of $A$. augusta and Azadirachta indica lowered blood sugar in alloxan diabetic rats when administered orally (Halim and Hossain 2002). A number of researchers reported the repellent activities of different plants on storage pests Mc Donald et al.1970, Talukder and Howse1995, Pramanik et al. 2009, Abdullah Jilani et al. 1988, Huang et al.1997. No published information was available on the repellent activities of the extractives of $A$. augusta. The following investigation reports the repellent effects of the chloroform extracts of various parts of $A$. augusta on a major storage pest, Tribolium castaneum (Herbst).

\section{Materials and Methods}

Preparation of plant materials for extraction: The fresh leaves, root wood, seeds, stem bark, and stem wood of $A$. augusta were collected from the campus of the University of Rajshahi, Bangladesh. After drying under shade the plant materials were powdered in a grinder separately avoiding excess heat during grinding.

Chemical extraction of the collected materials: Chloroform was selected as a solvent to extract different parts of $A$. augusta separately. The ground dried materials, viz. leaves, root wood, seeds, stem bark, and stem-wood were extracted with sufficient amounts of chloroform $(500 \mathrm{~g} \times 1500 \mathrm{ml} \times 3$ times) for each of the items. Separate extracts were collected by the cool method after $72 \mathrm{hrs}$ of plunging for each of the materials. Extracts, thus obtained, were subjected to filtration and evaporation of the solvent. The residue was left and kept in a refrigerator after proper labeling.

Preparation of doses with the crude extracts: A general concentration for each of the extracts was selected as stock dose to make other successive doses by serial dilution to give 314.540, 157.270, 78.635, $39.318,19.659$ and, $9.831 \mu \mathrm{g} / \mathrm{cm}^{2}$ for all the extracts. 
Application of doses: The repellency test used in this experiment was adopted from McDonald et al. (1970) with some modifications by Talukder and Howse $(1993,1994)$. Half filter paper discs (Whatman No. 40, diameter $9 \mathrm{~cm}$ ) were prepared and selected doses of all the $\mathrm{CHCl}_{3}$ extracts were separately applied onto each of the half-discs and allowed to dry out in the air for 10 mins. Each treated half-disc was then attached lengthwise, edge-to-edge, to a control half-disc with adhesive tape and placed in petri dishes. The orientation of the same was changed in the replica to avoid the effects of any external directional stimulus affecting the distribution of the test insects. Ten adult insects were released in the middle of each of the filter-paper circles and each test was replicated five times.

Observation and analysis of repellency data: Insects that settled on the non-treated half of the filter paper discs were counted after $1 \mathrm{~h}$ and then at hourly intervals for $5 \mathrm{hrs}$. The average of the counts was converted to percent repellency $(P R)$ using the formula of Talukder and Howse $(1993,1995)$ :

$P R=2(C-50)$,

Where, $C$ is the percentage of insects on the untreated half of the disc. Positive values expressed repellency and negative values for attractant activity. The data obtained as percent repellency was developed by arcsin transformation for the calculation of ANOVA. The experiment was conducted at room temperature of $30 \pm{ }^{\circ} \mathrm{C}$..

\section{Results and Discussion}

All the test extracts of seed, leaves, root wood, stem bark and stem wood of $A$. augusta collected in chloroform showed repellent activity against adult beetles of $T$. castaneum at dose levels of 314.540 , $157.270,78.635,39.318,19.659$ and, $9.831 \mu \mathrm{g} / \mathrm{cm}^{2}$ on filter paper (Table 1). The statistical analyses of the data are given in Table 2. According to the intensity of repellency the results could be arranged in the order: stem bark >seed > root wood > leaf > stem wood and in all the cases significant differences were obtained.

Table 1. Repellency of $T$. castaneum adults by $\mathrm{CHCl}_{3}$ extracts of different parts of $A$. augusta

\begin{tabular}{|c|c|c|c|c|c|c|}
\hline \multirow{2}{*}{$\begin{array}{l}\text { Material } \\
\text { extracted }\end{array}$} & \multirow{2}{*}{ Dose $\left(\mu \mathrm{g} / \mathrm{cm}^{2}\right)$} & \multicolumn{5}{|c|}{ Repellency percentage (arcsin) at intervals } \\
\hline & & $1^{\text {st }}$ hour & $2^{\text {nd }}$ hour & $3^{\text {rd }}$ hour & $4^{\text {th }}$ hour & $5^{\text {th }}$ hour \\
\hline \multirow{12}{*}{ 苂 } & & 66.67 & 80.00 & 40.00 & 60.00 & 73.32 \\
\hline & $4+4.070$ & $(54.70)$ & $(63.44)$ & $(39.23)$ & $(50.77)$ & $(58.89)$ \\
\hline & & 80.00 & 46.67 & 33.32 & 40.00 & 66.67 \\
\hline & & $(63.44)$ & $(43.05)$ & $(35.24)$ & (39.23) & $(54.70)$ \\
\hline & 79625 & 53.32 & 60.00 & 40.00 & 33.32 & 40.00 \\
\hline & & $(46.89)$ & $(50.77)$ & $(39.23)$ & $(35.24)$ & (39.23) \\
\hline & & 53.32 & 20.00 & 26.67 & 13.32 & 6.67 \\
\hline & & $(46.89)$ & $(26.56)$ & $(31.05)$ & $(21.39)$ & $(14.89)$ \\
\hline & 10650 & 6.67 & 20.00 & 6.67 & 6.67 & 20.00 \\
\hline & & $(14.89)$ & $(26.56)$ & $(14.89)$ & $(14.89)$ & $(26.56)$ \\
\hline & 9830 & 6.67 & 20.00 & 20.00 & 13.32 & 20.00 \\
\hline & & (14.89) & $(26.56)$ & $(26.56)$ & $(21.39)$ & $(26.56)$ \\
\hline
\end{tabular}


Contd. Table 1. Repellency of $T$. castaneum adults by $\mathrm{CHCl}_{3}$ extracts of different parts of $A$. augusta

\begin{tabular}{|c|c|c|c|c|c|c|}
\hline \multirow{2}{*}{$\begin{array}{c}\text { Material } \\
\text { extracted }\end{array}$} & \multirow{2}{*}{ Dose $\left(\mu \mathrm{g} / \mathrm{cm}^{2}\right)$} & \multicolumn{5}{|c|}{ Repellency percentage (arcsin) at intervals } \\
\hline & & $1^{\text {st }}$ hour & $2^{\text {nd }}$ hour & $3^{\text {rd }}$ hour & $4^{\text {th }}$ hour & $5^{\text {th }}$ houl \\
\hline \multirow{12}{*}{ 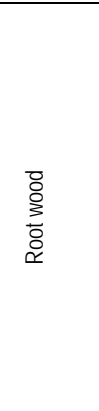 } & \multirow{2}{*}{314.540} & 80.00 & 66.67 & 66.67 & 40.00 & 60.00 \\
\hline & & $(63.44)$ & $(54.70)$ & $(54.70)$ & $(39.23)$ & $(50.77)$ \\
\hline & \multirow{2}{*}{157.270} & 60.00 & 40.00 & 60.00 & 46.67 & 53.32 \\
\hline & & $(50.77)$ & $(39.23)$ & $(50.77)$ & $(43.05)$ & $(46.89)$ \\
\hline & \multirow{2}{*}{78.635} & 46.67 & 40.00 & 20.00 & 40.00 & 33.32 \\
\hline & & $(43.05)$ & $(39.23)$ & $(26.56)$ & $(39.23)$ & $(35.24)$ \\
\hline & \multirow{2}{*}{39.318} & 26.67 & 6.67 & 13.32 & 20.00 & 26.67 \\
\hline & & $(31.05)$ & $(14.89)$ & $(21.39)$ & $(26.56)$ & (31.05) \\
\hline & \multirow{2}{*}{19.659} & 6.67 & 6.67 & 13.32 & 33.32 & 6.67 \\
\hline & & $(14.89)$ & $(14.89)$ & (21.39) & (35.24) & $(14.89)$ \\
\hline & \multirow{2}{*}{9.830} & 20.00 & 13.32 & 13.32 & 13.32 & 6.67 \\
\hline & & $(26.56)$ & $(21.39)$ & $(21.39)$ & (21.39) & $(14.89)$ \\
\hline \multirow{12}{*}{ 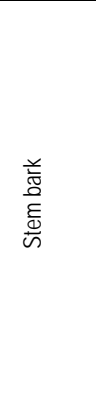 } & \multirow{2}{*}{314.540} & 80.00 & 80.00 & 60.00 & 80.00 & 73.32 \\
\hline & & $(63.44)$ & $(63.44)$ & $(50.77)$ & $(63.44)$ & (58.89) \\
\hline & \multirow{2}{*}{157.270} & 66.67 & 60.00 & 66.67 & 66.67 & 66.67 \\
\hline & & $(54.70)$ & $(50.77)$ & $(54.70)$ & $(54.70)$ & $(54.70)$ \\
\hline & \multirow{2}{*}{78.635} & 40.00 & 40.00 & 40.00 & 60.00 & 40.00 \\
\hline & & $(39.23)$ & $(39.23)$ & (39.23) & $(50.77)$ & (39.23) \\
\hline & \multirow{2}{*}{39.318} & 40.00 & 33.32 & 26.67 & 26.67 & 20.00 \\
\hline & & (39.23) & $(35.24)$ & $(31.05)$ & (31.05) & (26.56) \\
\hline & \multirow{2}{*}{19.659} & 26.67 & 26.67 & 20.00 & 26.67 & 6.67 \\
\hline & & $(31.05)$ & $(31.05)$ & $(26.56)$ & $(31.05)$ & $(14.89)$ \\
\hline & \multirow{2}{*}{9.830} & 6.67 & 13.32 & 26.67 & 6.67 & 13.32 \\
\hline & & $(14.89)$ & $(21.39)$ & (31.05) & $(14.89)$ & (21.39) \\
\hline \multirow{12}{*}{ 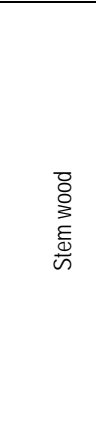 } & \multirow{2}{*}{314.540} & 60.00 & 40.00 & 66.67 & 46.67 & 46.67 \\
\hline & & $(50.77)$ & $(39.23)$ & $(54.70)$ & $(43.05)$ & (43.05) \\
\hline & \multirow{2}{*}{157.270} & 60.00 & 60.00 & 33.32 & 33.32 & 46.67 \\
\hline & & $(50.77)$ & $(50.77)$ & $(35.24)$ & (35.24) & $(43.05)$ \\
\hline & \multirow{2}{*}{78.635} & 33.32 & 26.67 & 26.67 & 6.67 & 26.67 \\
\hline & & $(35.24)$ & $(31.05)$ & (31.05) & $(14.89)$ & $(31.05)$ \\
\hline & 30210 & 26.67 & 20.00 & 13.32 & 6.67 & 40.00 \\
\hline & 39.318 & (31.05) & (26.56) & (21.39) & (14.89) & $(39.23)$ \\
\hline & 19650 & 6.67 & 13.32 & 13.32 & 26.67 & 20.00 \\
\hline & 19.659 & $(14.89)$ & $(21.39)$ & (21.39) & (31.05) & (26.56) \\
\hline & 0830 & 6.67 & 6.67 & 6.67 & 13.32 & 6.67 \\
\hline & 9.830 & (14.89) & $(14.89)$ & (14.89) & (21.39) & (14.89) \\
\hline & 314540 & 93.34 & 73.34 & 80.00 & 86.67 & 86.67 \\
\hline & 314.540 & $(75.00)$ & (58.89) & $(63.44)$ & (68.53) & (68.53) \\
\hline & 157270 & 60.00 & 80.00 & 73.34 & 60.00 & 53.34 \\
\hline & 157.210 & (50.77) & (63.44) & $(58.89)$ & (50.77) & $(46.89)$ \\
\hline & 78635 & 60.00 & 60.00 & 66.67 & 53.34 & 60.00 \\
\hline & 10.035 & $(50.77)$ & $(50.77)$ & $(54.70)$ & $(46.89)$ & $(50.77)$ \\
\hline$\stackrel{\Phi}{\infty}$ & 39318 & 53.34 & 40.00 & 53.34 & 40.00 & 53.34 \\
\hline & & $(46.89)$ & $(39.23)$ & (46.89) & (39.23) & (46.89) \\
\hline & 19659 & 40.00 & 46.67 & 40.00 & 33.34 & 33.34 \\
\hline & 19.659 & $(39.23)$ & $(43.05)$ & $(39.23)$ & $(35.24)$ & $(35.24)$ \\
\hline & 0830 & 26.67 & 26.67 & 20.00 & 33.34 & 33.34 \\
\hline & 9.830 & (31.05) & (31.05) & $(26.56)$ & (35.24) & $(35.24)$ \\
\hline
\end{tabular}


Table 2. ANOVA results of repellency by $A$. augusta extracts against $T$. castaneum adults.

\begin{tabular}{|c|c|c|c|c|c|c|}
\hline Test material & Source of Variation & SS & $d f$ & MS & F-ratio & P-value \\
\hline \multirow{4}{*}{$\begin{array}{l}\bar{\Xi} \\
\mathbb{N} \\
\text { ஸు }\end{array}$} & Between dose levels & 3861.734 & 5 & 772.3468 & $31.06174^{\star \star \star}$ & 8.99E-09 \\
\hline & $\begin{array}{l}\text { Between time } \\
\text { intervals }\end{array}$ & 30.21025 & 4 & 7.552562 & 0.303744 & 0.872006 \\
\hline & Error & 497.2978 & 20 & 24.86489 & & \\
\hline & Total & 4389.242 & 29 & & & \\
\hline \multirow{4}{*}{ 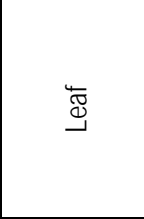 } & Between dose levels & 4806.357 & 5 & 961.2714 & $13.87454^{\star \star *}$ & 6.35E-06 \\
\hline & $\begin{array}{c}\text { Between time } \\
\text { intervals }\end{array}$ & 513.2012 & 4 & 128.3003 & 1.851827 & 0.158545 \\
\hline & Error & 1385.662 & 20 & 69.28311 & & \\
\hline & Total & 6705.22 & 29 & & & \\
\hline \multirow{4}{*}{ 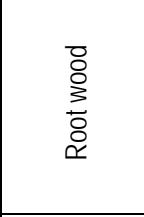 } & Between dose levels & 4671.159 & 5 & 934.2319 & $19.87131^{\star * *}$ & 3.86E-07 \\
\hline & $\begin{array}{l}\text { Between time } \\
\text { intervals }\end{array}$ & 198.6403 & 4 & 49.66007 & 1.05628 & 0.403684 \\
\hline & Error & 940.282 & 20 & 47.0141 & & \\
\hline & Total & 5810.082 & 29 & & & \\
\hline \multirow{4}{*}{$\begin{array}{l}\overline{0} \\
\vdots \\
\stackrel{0}{\Phi} \\
\stackrel{\Phi}{\omega}\end{array}$} & Between dose levels & 3401.835 & 5 & 680.3671 & $13.35112^{\star \star \star}$ & $8.45 \mathrm{E}-06$ \\
\hline & $\begin{array}{l}\text { Between time } \\
\text { intervals }\end{array}$ & 159.3931 & 4 & 39.84828 & 0.781959 & 0.550127 \\
\hline & Error & 1019.191 & 20 & 50.95954 & & \\
\hline & Total & 4580.419 & 29 & & & \\
\hline \multirow{4}{*}{ 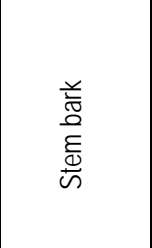 } & $\begin{array}{l}\text { Between dose } \\
\text { levels }\end{array}$ & 5949.248 & 5 & 1189.85 & $39.22012^{\star \star \star}$ & 1.15E-09 \\
\hline & $\begin{array}{l}\text { Between time } \\
\text { intervals }\end{array}$ & 97.87965 & 4 & 24.46991 & 0.806583 & 0.535457 \\
\hline & Error & 606.7547 & 20 & 30.33773 & & \\
\hline & Total & 6653.883 & 29 & & & \\
\hline
\end{tabular}

** $=P<0.01 ;{ }^{*}=P<0.05$

Our results are in agreement with similar works of McDonald et al. (1970), Khan (1981), Talukder and Howse (1995), Hebbalkar et al. (1992) and Pugazhvendan et al. (2012). Abdullah et al. (2011) assessed the mortality and repellency of the chloroform extracts of different parts of Urena sinuata on T. castaneum adults. The root and stem extracts showed significant repellent effects on the beetles but the fruit and leaf extracts produced no repellency at all. The repellency record triggers a hope for the use of $A$. augusta extracts as repellents since most of the extracts repelled the beetles significantly. Singh et al. (2001) carried out antifeedant activity tests of some (of bioactive potentials) plants that help understanding repellent potentiality of some medicinal plant extracts. Mondal et al. (2011) assessed the repellent activity of Derris indica extracts against $T$. castaneum adults. The fruit shell, leaves, seed and stem bark extracts showed repellent activity but the stem wood, root bark and root wood extracts produced no repellency at all. 


\section{Conclusion}

The present results revealed that $A$. augusta extracts can be used as reduced risk repellent compounds in the grain and cereal stores to manage the population of $T$. castaneum. The results also seem to be encouraging when there is a greater need for environment-friendly pesticides than ever before.

\section{Acknowledgement}

The authors remain grateful to the Chairman, Department of Zoology, University of Rajshahi, Bangladesh, for kindly supplying the required laboratory facilities to conduct the experiment.

\section{References}

Abdullah M, PK. AK, Saleh DKMA, Khan AR, Islam R, Islam N. 2011. Insecticidal and repellent activities of the chloroform extracts of Urena sinuata L. against Tribolium castaneum (Herbst) adults. Univ j zool Rajshahi Univ 30, 25-28.

Anonymous, 2006. "The wealth of India" dictionary of Indian raw materials and industrial products. The Council of Scientific and Industrial Research, NISCAIR Press Publisher; New Delhi, pp.222.

Farhana K, Islam H, Islam N. 2006. Toxicity and repellent activity of three spices materials on Tribolium castaneum (Hbst.) J Bio-sci 14, 131-134.

Hanif A, Sh H, Agarwal B, Mohammed R, Rowank J. 2010. (A journal of plants, people and applied research). Ethnobotany research and Applications 8, 61-74.

Halim EM, Hussain A. 2002. Hypoglycemic, hypolipidemic and antioxidant properties of combination of Curcumin longa Linn. and partially purified product from Abroma augusta L. in Streptozotocin induced diabetes. Indian J Clin Biochem 17(2), 33-43. http://dx.doi.org/10.1007/BF02867969

Hebbalkar DS, Hebbalkar GD, Sharma RN, Joshi VS, Bhat VS. 1992. Mosquito repellent activity of oils from Vitex negundo Linn. leaves. Indian J Med Res 95, 200-203.

Huang Y, Tan JMWL, Kim RM, Ho SH. 1997. Toxic and antifeedants action of nutmeg oil against Tribolium castaneum (Herbst) and Sitophilus zeamais. Motech J stored Prod Res 33(4), 289-298. http://dx.doi.org/10.1016/S0022$\underline{474 X \% 2897 \% 2900009-X}$

Jilani G, Saxena RC, Rueda BP. 1988. Repellent and growth inhibiting effects of turmeric oil, sweet flag oil and " Margoson-O" on red flour beetle (Coleoptera:Tenebrinoidae). J econ Ent 81(4),1226-1230.

Khan MA. 1981. Repellents fur vorratsschadliche Insekten. Anz. Schädlingskde. Pflanzenschutz. Umwelschutz 54, $70-$ 77.

Kritikar KR, Basu BD. 1999. Text book of "Indian medicinal plants", vol.1 2nd ed. (Surendra Nath Basu publishers, Bahadur Ganj, Allahabad) International Book Distributor. pp 379.

Mondal OA, Islam H, Biswas S, Islam N. 2011. Repellent activity of Derris indica extracts against Tribolium castaneum (Hbst.) adults. J Life Earth Sci 6, 113-115.

McDonald LL, Guy RH, Speirs RD.1970. Preliminary evaluation of new candidate materials as toxicants, repellents and attractants against stored-product insects. Agricultural Research Service, U. S. Department of Agriculture, Washington D.C., Marketing Research Report No. 882.

Nandkarni KM. 2002. Indian materia medica, vol. I. Bombay Popular Prakashan, Mumbai.

Pramanik MS, Akter MY, Ekram AE, Islam H, Islam N.2009. Screening of Glycosmis pentaphylla for cytotoxic and repellent potentials against Artemia salina nauplii and Tribolium castaneum adults. J Life Earth Sci 3(4), 33-36.

Prajapati ND, Purohit SS, Sharma AK, Kumar T.2003. A hand book of medicinal plants, A complete source book. Agrobios (India) Publisher; Jodhpur 337-344 pp. 
Pugazhvendan SR, Ronald Ross P, Elumalai K. 2012. Insecticidal and repellant activities of four indigenous medicinal plants against stored grain pest, Tribolium castaneum (Herbst) (Coleoptera: Tenebrionidae). Asian Pac J Trop Dis 2, S16-S20. http://dx.doi.org/10.1016/S2222-1808\%2812\%2960116-9

Rahmatullah M, Bachar C, Rahman S, Jahan R. 2010. Advance in natural and applied science 4(2), 163-173.

Singh IB, Singh K, Singh HN. 2001. Relative efficacy of certain plant extracts as antifeedants against gram pod borer. Bioved 12(1/2), 41-44.

Talukder FA, Howse PE. 1993. Deterrent and insecticidal effects of extracts of pitraj, Aphanamixis polystachea (Meliaceae), against Tribolium castaneum in storage. J Chem Ecol 19 (11), 2463-2471. http://dx.doi.org/10.1007/BF00980683

Talukder FA, Howse PE.1994. Efficacy of pithraj (Aphanamixis polystachya) seed extracts against stored-product pests. Proc Int Wkg Conf on Stored-prod Prot (Canberra, Australia) 2, 848-852.

Talukder FA, Howse PE. 1995. Evaluation of Aphanamixis polystachya as a source of repellents, anti-feedants, toxicants and protectants in storage against Tribolium castaneum (Herbst). J Stored Prod Res 31, 55-61. http://dx.doi.org/10.1016/0022-474X\%2894\%2900036-S 